\title{
Sestrinske intervencije kod kontrastne transezofagusne ehokariografije u otkrivanju pretkomorskih šantova
}

\author{
Marina Parandilovic, VMC Karaburma
}

Sažetak: Transezofagusna ehokardiografija (TEE) je ehokardiografski pregled srca iz ezofagusa koji se obavlja modifikovanom endoskopskom sondom sa ultrazvučnim transđuserom na vrhu. Jedna od čestih indikacija za izvođenje TEE pregleda je pozitivan „,bubble test"kod neuroloških bolesnika. Pregled izvodi lekar uz asistenciju dve medicinske sestre. Prilikom pregleda pristupa se aplikovanju kontrastnog sredstva kako bi se utvrdilo postojanje predkomorskih šantova. Neophodna je tesna sradnja između članova tima što je preduslov brze i kvalutetne dijagnostike.

Ključne reči: transezofagusna ehokardiografija, interatrijalni septum, aktivnosti medicinske sestre

Abstract: Transesophageal echocardiography (TEE) is echocardiographic heart examination from the esophagus which is performed by the modified echocardiography with ultrasound transducer on the top. One of the frequent indications for TEE is positive "bubble test“ in patients with previous neurological disease. Examination is performed by the doctor with assistance of two nurses. During the examination contrast is used for the confirmation of the atrial shants existance. Good coopertaion between members is mandatory for the quick and good diagnostic.

Key words: Transesophageal echocardiography, interatrial septum, nurses activities

\section{UVOD}

$\mathrm{E}$ hokardiografski pregled srca iz ezofagusa postao je značajan pristup sa izvanrednim kvalitetom prikaza zbog blizine srca i ezofagusa, gubitka interferencije sa okolnim strukturama i mogućnosti primene sondi većih frekvencija koje daju bolju rezoluciju. Transezofagusni ehokardiografski pregled (TEE) se obavlja modifikovanom endoskopskom sondom sa ultrazvučnim transđuserom na vrhu sonde, što omogućava preciznu vizuelizaciju srčanih struktura. TEE je seminvazivna metoda koja se izvodi brzo, čak i kod teških bolesnika.

Jedna od čestih indikacija za transezofagusnu ehokardiografiju je pozitivan „bubble test“ kod neuroloških bolesnika. Radi se o bolesnicima sa krizama svesti (TIA, CVI) kod kojih je tokom neurološke obrade dobijen pozitivan „bubble test“, što ukazuje na postojanje razlišitih anatomskih varijanti, ali i patoloških stanja koja mogu biti povezana sa sistemskom embolizacijom. Pre svega se misli na aneurizmu interatrijalnog septuma (IAS), otvoreni-patentni foramen ovale (PFO) ili atrijalni septalni defekt (ASD). Radi ptvrde ili isključivanja ovih promena potrebna je što bolja vizuelizacija interatrijalnog septuma što nam omogućava kontrastna TEE.

Bubble test (test mehurićima) se izvodi kod neuroloških bolesnika tako što se prilikom transkaranijalnog ultrazvuka bolesniku intravenski ubrizga izmućkani fizioločki rastvor i prati se prusustvo kontrasta transkranijalnim ultrazvukom. Ultrazvučna meta su mehurići gasa koji su nastali prilikom mućkanja rastvora. Ukoloko je test pozitivan to ukazuje na eventualno postojanje otvora na nivou predkomorskog septuma.

Primena kontrastnog sredstva u neurologiji (bubble test), ne može da identifikuje put kontrasta ubrizganog u perifernu venu, što TEE pregledu daje veći značaj. TEE pregled omogučava da utvrdimo da li se kontrast pojavljuje usled prolaska kroz interatrijalni septum ili predstavlja „transpulmonalni“ prolaz.

\section{Anomalije predkomorskog septuma}

Aneurizma predkomorskogseptuma (IAS) je kongenitalna anomalija predkomorske pregrade koja se definiše kao hipermo-

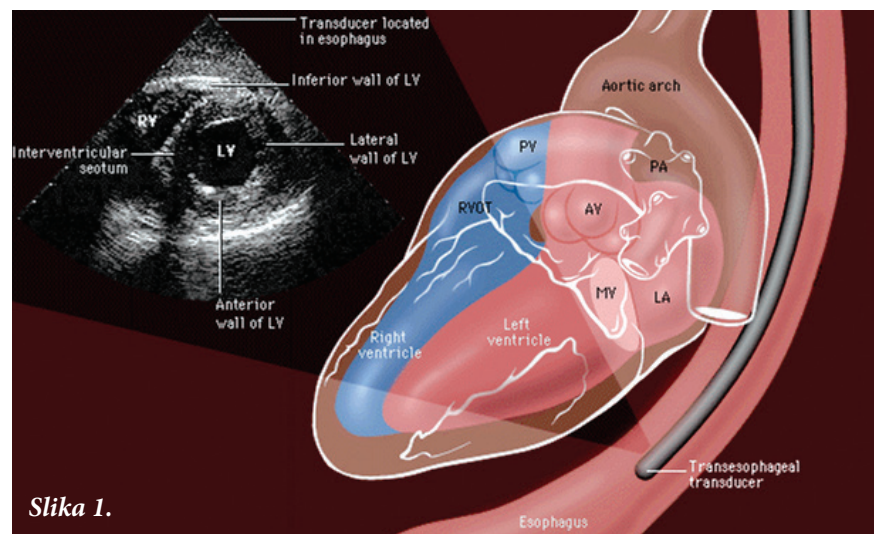

bilno izbočenje predkomorske pregrade. Posledica je kongenitalnog defekta vezivnog tkiva. U populaciji bolesnika sa ishemijskim moždanim udarom mlađih od 40 godina učestalost IAS se kreće 20-28\%. Smatra se da sama aneurizma može biti izvor trombotičnog materijala, a često je i udružena sa patentnim foramenom ovale (PFO) ili atrijalnim septalnim defektom (ASD).

Otvoreni-patentni foramen ovalr (PFO) je anomalija predkomorske pregrade koja nastaje usled nepotpunog srastanja septuma primum i sekundum posle rođenja zbog čega zaostaje komunikacija između dve predkomore. Sreće se kod približno $30 \%$ odraslih. PFO je odgovoran je za značajan procenat ishemijskih moždanih udara, posebno kod mlađih bolesnika. Moguć mehanizam je paradoksna embolija trombotičnim materijalom iz venskog sistema donjih ekstremiteta i karlice.

Atrilani septalni defekt (ASD) je urođena srčana mana koja označava abnormalnu komunikaciju između predkomora kroz predkomorski septum. Pošto postoji otvopr na predkomorskoj pregradi postoji opasnost da sitni trombi prolaze iz desne u levu predkomoru dospevaju u levu komoru, a zatim preko aorte u moždanu cirkulaciju i mogu dovesti do ishemijskih moždanih lezija.

\section{MATERIJAL I METODOLOGIJA}

Ispitivanjem je bilo obuhvaćeno 100 bolesnika lečenih zbog ishemijskih moždanih lezija u periodu od 1.09. 2011. do 
1.09.2013. god. kod kojih je TEE pregled indikovan nakon pozitivnog „bubble testa“. Proceduru izvodi lekar uz asistenciju dve medicinske sestre. Dužina pregleda je 15-20 minuta.

\section{Sestrinske intervencije prilikom izvođenja procedure}

Pre izvođenja procedure, medicinska sestra objašnjava bolesniku postupak izvođenja i obavezno vrši psihološku pripremu. Uzima kratku anamnezu i proverava da li postoje kontraindikacije za izvođenje TEE pregleda. Zabranjeno je uzimanje hrane najmanje $4 \mathrm{~h}$ pre pregleda . Kontraindikacija za izvođenje pregleda je i ako postoje varikoziteti, divertikulumi jednjaka, konstrikcije jednjaka, ezofagitis, hiatus hernija. Dobijamo podatak o alergijama na lekove, kao i prisustvu zubne proteze. Ukoliko je pacijent na antikoagulantnoj terapiji, dan pre pregleda prepolovi propisanu dozu i dolazi sa vrednostima INR-a. Nakon obavljenog razgovora bolesnik potpisuje pristanak. Pre TEE pregleda obavi se transtoraksni pregled, a deo pregleda sa ehokardiografskim merenjima obavlja medicinska sestra.
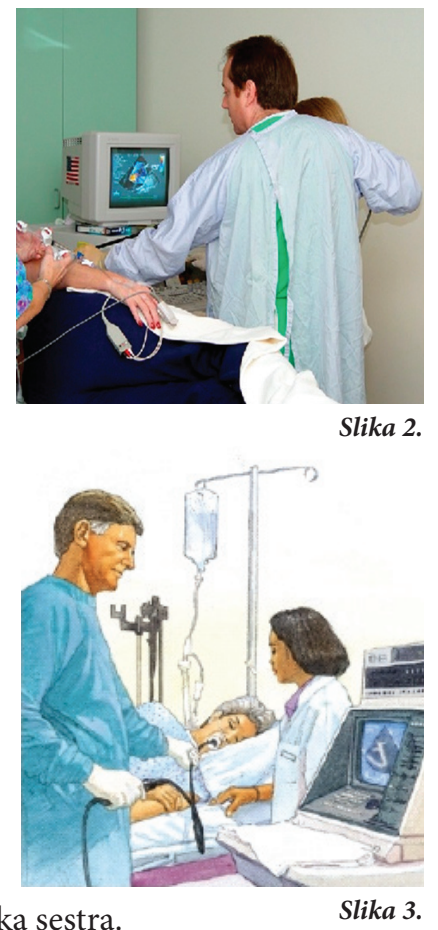

Nakon obavljenog transtoraksnog pregleda, jedna sestra plasiara bolesniku IV kanilu većeg promera u kubitalnu venu, priključuje ga na EKG monitoring i postavlja na levi bok sa blago savijenom glavom prema kolenima. Druga sestra priprema ultrazvučni aparat, transezofagusnu sondu, urgentnu terapiju i navlači kontrast. Kao kontrastno sredstvo se koristi $5 \%$ glukoza ili $0.9 \% \mathrm{NaCl}$.

Ukoloko postoji indikacija pacijentu se pre pregleda daje antibiotik (prevencija bakterijskog endokarditisa). Grlo se anes- tezira Xilokain sprejom, i stavlja se štitnik za zube. Po potrebi pacijent se sedira ukoliko je suviše uznemiren i ne sarađuje.

Lekar plasira transezofagusnu sondu dok mu medicinska sestra asistira pri proveri ispravnost i aktiviranju sonde. Sve vreme bolesniku se prati opšte stanje i vitalni parametri . Dok jedna sestra pridržava bolesnika, pridržava štitnik za zube i pomaže bolesniku da ostane u odgovarajućem položaju, druga sestra ubrizgava kontrast. U brizgalicu od $20 \mathrm{ml}$, navuče se 10ml Glukoze ili NaCl-a, energično se izmućka, a zatim aplikuje velikom brzinom. Sve vreme se radi pod kontrolom ultrazvuka. Ultrazvučna meta su mehurići gasa koji nastanu prilikom mućkanja i oni omogućavaju da se vizuelizuje kontrast u desnim srčanim šupljinama. Ukoliko se kontrast nakon tri srčana ciklusa pojavi i u levim srčanim šupljinama to je dokaz da postoji komunikacija između predkomora i to može biti razlog nastanka moždanog udara. Kasnije pojavljivanje mehurića u levoj predkomori ukazuje na prolaz izuzetno sitnih mehurića kroz plučne kapilare i njihov prelazak preko plućnih vena u levu predkomoru.

Potrebna je izuzetna koordinacija sestre i lekara pri primeni manevra za prolazno povećanje pritiska u desnoj predkomori simultano sa aplikacijom kontrastnog sredstva, što povećava mogučnost dokazivanja desno levog šanta na nivou predkomora.

Nakon pregleda pacijent se zbrinjava i opservira. Objasni mu se da ne sme uzimati hranu i vodu naredna $2 \mathrm{~h}$ zbog lokalne anestezije grla. Sonda se mehanički čisti, pere, a zatim steriliše. Snimljeni podaci se arhiviraju i sve se dokumentuje u odgovarajućim protokolima.

\section{REZULTATI}

Pozitivan „bubble test“ i normalan nalaz na predkomorskom septumu utvrđen je kod $40 \%$ bolesnika, dok je u $60 \%$ utvrđeno postojanje neke od anomalija predkomorskog septuma. Najčešća je udruženost aneurizme interatrijalnog septuma (IAS) i (PFO) u 22\% bolesnika, izolovani PFO u 18\%, izolovane IAS u $16 \%$, dok je defekt predkomorskog septuma utvrđen samo u $4 \%$ bolesnika (videti tabelu 1). U 33\% bolesnika sa pozitivnim »bubble testom« kontrastnom ehokardiografijom je utvrđeno je postojanje šanta na nivou predkomora.

\begin{tabular}{|c|c|c|c|c|c|c|c|c|}
\hline \multirow[t]{2}{*}{ STAROST } & \multicolumn{2}{|c|}{ POL } & \multirow[t]{2}{*}{ AIAS+PFO } & \multirow[t]{2}{*}{ PFO } & \multirow[t]{2}{*}{ AIAS } & \multirow[t]{2}{*}{ ASD } & \multirow{2}{*}{$\begin{array}{l}\text { NORMALAN } \\
\text { NALAZ } \\
\end{array}$} & \multirow[t]{2}{*}{ UKUPNO } \\
\hline & M & $\ddot{z}$ & & & & & & \\
\hline $21-65$ & 69 & 31 & 22 & 18 & 16 & 4 & 40 & 100 \\
\hline
\end{tabular}

\section{ZAKLJUČAK}

Kontrastna transezofagusna ehokardiografija je pouzdana, sigurna i lako primenjiva metoda koja omogućava potvrdu/ isključivanje intrakardijalnih šantova. Medicinska sestra odgovorno i svojom obučenošću prva pruža adekvatne medicinske ehokardiografske podatke doktoru tokom transtoraksnog pregleda. Vrši osnovna ehokardiografska merenja i nalaz referiše lekaru. Asistira tomom transezofagusnog pregleda i ona je kompetentan i neizbežan član ehokardiografskog tima. Kako bi bila ravnopravan član tima neophodno je stalno usavršavanje i proširivanje znanja. Dobra organizacija i visoka stručnost svih članova tima su preduslov brze i kvalitetne dijagnostike.

\section{Literatura:}

1. Bosković S.: Zdravstvena nega u internoj medicini, Finegraf, Beograd, 2014.

2. Fegenbaum S.: Echocardiograph, 2005.

3. Jurilj R., Božić I., Ehokardiografija, Medicinska naklada, Zagreb, 2007. .

4. Manojlović S., Matić Đ., Zdravstvena nega u internoj medicini, Beograd, 2010.

5. Simin N., Ehokardiografija, Beograd, 2001.

6. Vujisić B. I saradnici, ACTACLINICA Odabrana poglavlja iz ehokardiografije, Klinički centar Srbije, Beograd, 2011. 